\title{
EVALUASI EFEKTIVITAS PENGENDALIAN INTERN SISTEM INFORMASI AKUNTANSI PENGGAJIAN RSUP. PROF. DR. R. D. KANDOU MANADO
}

\author{
Richard Antonio Rompas ${ }^{1}$, Sifrid Pangemanan ${ }^{2}$, Meily Kalalo ${ }^{3}$ \\ ${ }^{1,2,3}$ Jurusan Akuntansi, Fakultas Ekonomi dan Bisnis, Universitas Sam Ratulangi, Jl. Kampus Bahu, Manado, \\ 95115, Indonesia \\ E-mail : Richardrompas.rr@gmail.com
}

\begin{abstract}
Accounting information systems is a supportive factor in the companny's performance. Company will require SIA in this time because SIA provide financial effectively and efficiently. The purpose of this study is to determine whether the effectiveness of internal control payroll accounting information system RSUP. Prof. Dr. R. D. Kandou Mando has gone well. The author uses descriptive analysis where research start by collecting and sifting through incoming information thoroughly and detail later elaborated in order to obtain a clean picture. The results of the study concluded that the payroll accounting system implemented by RSUP. Prof. Dr. R. D. Kandou Manado already have a good system and effective and meet the element of internal control to improve companny's performance. But thare are very few weaknesses that auditing section not conducting regular monitoring three months once.
\end{abstract}

Keywords: Accounting information system, payroll, effectiveness of internal control

\section{PENDAHULUAN}

Dalam perusahaan perkembangan teknologi yang pesat saat ini, sebagian masyarakat semakin merasakan bahwa informasi merupakan kebutuhan yang sangat penting. Demikian juga pada suatu perusahaan diperlukan adanya sistem informasi yang baik. Pada dasarnya setiap perusahaan memiliki tujuan untuk memperoleh keuntungan.

Perkembangan dunia yang pesat ini, menimbulkan persaingan yang semakin ketat. Persaingan bukan saja muncul dari perusahaan yang baru berdiri, namun perusahaan yang sudah lama berdiri pun pasti timbul persaingan. Dalam menghadapi persaingan yang ketat dibutuhkan menejemen yang handal dan mampu mengantisipasi setiap persaingan dan dapat menjalankan perusahaan secara efektif dan efisien.

Perlu kita sadari bahwa salah satu faktor penentu yang dapat menghasilkan sumber daya yang berkualitas ini adalah kesehatan. Kenyataan menunjukan bahwa kesehatan yang baik akan meningkatkan produktivitas. Pentingnya masalah-masalah kesehatan harus disadari oleh pihak-pihak yang berkaitan baik pemerintah maupun swasta. Pemerintah sekarang ini sedang melakukan penigkataan layanan kesehaan kepada masyarakat. Wujud nyata perhatian pemerintah terhadap pembangunan kesehatan dengan usaha meningkatkan mutu dan layanan kesehatan, fasilitas layanan kesehatan, fasilitas layanan kesehatan penigkatan gizi masyarakat, Serta penigkatan peran masyarakat dalam upaya kesehatan.

Rumah sakit Prof.Dr. R. D. kandou Manado adalah rumah sakit kelas A dimana oprasionalnya secara penuh pada tahun 1995. Dan secara resmi dipindahkan ke Kecamatan Malalayang Manado dan diberi nama rumah sakit umum pusat. Sebagai organisasi public, Rumah sakit diharapkan mampu memberikan pelayanan kesehatan yang bermutu kepada masyarakat. Rumah sakit umum adalah rumah sakit yang memberikan pelayaan kesehatan yang bersifat dasar, Spesialistik dan subspesialistik, Seperti yang tertera dalam surat keputusan mentri RI No 983/Menkes/SK/XI/1992 
Karakteristik sistem Informasi akuntansi yang tersedia akan menjadi efektif apabila mendukung kebutuhan pengguna informasi atau pengambil keputusan. Hal ini sejalan dengan tingkat ketersediaan dari masing-masing karakteristik sistem informasi akuntansi tetapi ada faktor tertentu lainnya yang akan mempengaruhi tingkat terhadap sistem informasi akuntansi.

Akan tetapi, jika perusahaan semakin besar skala usahanya maka diperlukan internal auditor yang efektif, efisien, bertugas dan bertanggung jawab dalam melakukan pengawasan internal di dalam perusahaan. Dengan adanya internal auditor maka diharapkan segala kebijakan pimpinan perusahaan dapat dilaksanakan sebaik-baiknya, aset perusahaan dapat diamankan dan dapat memperoleh data akuntansi yang akurat dan terpercaya.

Internal auditor merupakan organ pendukung yang dibentuk direksi. Agar internal auditor perusahaan dapat berjalan dengan efektif, maka harus ada suatu bagian yang independen terhadap bagian lainnya yang melakukan penelitian dan pengkajian secara cermat dan terus menerus terhadap pengendalian intern perusahaan tersebut. Bagian ini dinamakan bagian pemeriksaan internal.

Internal auditing ialah suatu aktivitas penilaian secara bebas dan tidak memihak dalam suatu organisasi perusahaan untuk menilai akuntansi, keuangan dan kegiatan operasional lainnya sebagai dasar untuk memberikan rekomendasi yang konstruktif kepada pimpinan perusahaan dalam melaksanakan pengendalian.

\section{TINJAUAN PUSTAKA}

\subsection{Laporan Keuangan}

Pontoh (2013: 2) Menyatakan akuntansi keuangan merupakan bidang akuntansi yang menyediakan informasi akuntansi secara umum bagi pemakai untuk pengambilan keputusan yang ada diluar organisasi untuk pihak eksternal, seperti kreditur, investor dan lain-lain. Informasi keuangan dihasilkan berdasarkan prinsip akuntansi yang berlaku umum (PABU) atau Generally Accepted Accounting Principles (GAAP). Akuntansi keuangan berhubungan dengan masalah pencatatan transaksi untuk suatu perusahaan atau organisasi dan penyusunan berbagai laporan berkala dari hasil pencatatan.

\subsection{Tujuan Laporan Keuangan}

Akuntansi keuangan berhubungan dengan masalah pencatatan transaksi untuk suatu perusahaan atau organisasi dan penyusunan berbagai laporan berkala dari hasil pencatatan. Pontoh (2013: 2). Sedangkan dalam Standar Akuntansi Keuangan dijelaskan tentang tujuan laporan keuangan yang isinya tujuan laporan keuangan adalah menyediakan informasi yang menyangkut posisi keuangan, kinerja, serta perubahan posisi keuangan suatu perusahaan, yang bermanfaat bagi sejumlah besar pemakai dalam pengambilan keputusan ekonomi. (Harahap 2013).

Kieso \& Weygant, (2011) Akuntansi keuangan adalah serangkaian proses yang berujung pada penyusunan laporan keuangan yang berkaitan dengan perusahaan secara keseluruhan untuk digunankan oleh pengguna laporan keuangan baik internal maupun eksternal perusahaan. Akuntansi keuangan adalah bidang dalam akuntansi yang berfokus pada penyiapan laporan keuangan suatu perusahaan yang dilakukan secara berkala. Laporan ini sekaligus sebagai bentuk pertanggung jawaban manajemen kepada pemegang saham. Persamaan akuntansi yang digunakan adalah Aset $=$ Ekuitas + Liabilitas yang mengacu pada standar akuntansi keuangan.

\subsection{Konsep Sistem Informasi Akuntansi}

(Romney \& steinbart, 2015: 10,11) Sistem informasi akuntansi adalah kecerdasan, alat penyedia informasi, dari Bahasa tersebut. SIA dapat menjadi sistem manual pensil dan kertas, sistem kompleks yang menggunakan TI terbaru, atau suatu diantara keduanya. Terlepas dari pendekatan yang terambil, prosesnya adalah sama. SIA harus mengumpulkan, 
memasukan, memproses, menyimpan dan melaporkan data dan informasi. Kertas dan pensil atau perangkat lunak computer adalah alat yang digunakan untuk menghasilkan informasi.

\subsection{Definisi Sistem}

Menurut Rommey dan Steinbart (2015:3), sistem adalah suatu rangkaian yang terdiri dari dua atau lebih komponen yang saling berhubungan dan saling berinteraksi satu sama lain untuk mencapai tujuan dimana sistem biasanya terbagi dalam sub sistem yang lebih kecil yang mendukung sistem yang lebih besar. Menurut Gelinas Dan Dull (2012:11), Sistem merupakan seperangkat elemen yang saling bergantung yang sama-sama mencapai tujuan tertentu. Dimana sistem harus memiliki organisasi, hubungan timbal balik,integrase dan tujuan pokok.

Menurut Agus Mulyanto (2009:2), mempunyai karakteristik sebagai berikut:

a. Mempunyai Komponen (Components )

Suatu tidak berada dalam lingkungan yang kosong, tetapi sebuah berada dan berfungsi di dalam lingkungan yang berisi lainnya. Suatu terdiri dari sejumlah komponen yang saling berinteraksi, bekerja sama membentuk satu kesatuan. Apabila suatu merupakan salah satu dari komponen lain yang lebih besar, maka akan disebut dengan sub, sedangkan yang lebih besar tersebut adalah lingkungannya.

b. Mempunyai Batasan (Boundary)

Batas merupakan pembatas atau pemisah antara suatu dengan yang lainnya atau dengan lingkungan luarnya.

c. Mempunyai Lingkungan (Environment)

Lingkungan luar adalah apa pun di luar batas dari yang dapat mempengaruhi operasi, baik pengaruh yang menguntungkan ataupun yang merugikan. Pengaruh yang menguntungkan ini tentunya harus dijaga sehingga akan mendukung kelangsungan operasi sebuah. Sedangkan lingkungan yang merugikan harus ditahan dan dikendalikan agar tidak mengganggu kelangsungan sebuah.

Menurut Agus Mulyanto (2009:8), dapat di klasifikasikan berbagai sudut pandang, diantaranya adalah sebagai berikut:

1. abstrak (abstract sistem) dan fisik (physical sistem). abstrak (abstract sistem) adalah yang berupa pemikiran atau gagasan yang tidak tampak secara fisik. Sedangkan fisik (physical sistem) adalah yang ada secara fisik dan dapat dilihat dengan mata.

2. alamiah (natural sistem) dan buatan manusia (human made sistem).

alamiah adalah yang keberadaannya terjadi karena proses alam, bukan buatan manusia. Sedangkan buatan manusia (human made sistems) adalah yang terjadi melalui rancangan atau campur tangan manusia.

3. tertentu (deterministic sistem) dan tak tentu (probabilistic sistem) tertentu (deterministic sistems) yaitu yang operasinya dapat diprediksi secara cepat dan interaksi diantara bagian-bagiannya dapat dideteksi dengan pasti. Sedangkan tidak tentu (probabilistic sistems) yaitu yang hasilnya tidak dapat diprediksi karena mengandung unsur probabilitas.

\subsection{Definisi Informasi}

Informasi adalah data yang telah dikelola dan diproses untuk memberikan arti dalam memperbaiki proses pengambilan keputusan. Sebagaimana perannya, pengguna membuat keputusan yang lebih baik sebagai kuantitas dan kualitas dari penigkatan informasi. Perancang sistem informasi menggunakan teknologi informasi (TI - Informasi Tecnology) yang membantu pengambil keputusan menyaring dan meringkas informasi secara efektif (Romery \& stainbert, 2015:4). Menurut Agus Mulyanto (2009:12), Informasi adalah data yang diolah menjadi bentuk yang lebih berguna dan lebih berarti bagi yang menerimanya, sedangkan data merupakan sumber informasi yang menggambarkan suatu kejadian yang nyata. Menurut Jimmy (2008:8), Informasi adalah data yang telah diproses atau diolah ke 
dalam bentuk yang berarti untuk penerimanya dan merupakan nilai yang sesungguhnya atau dipahami dalam tindakan atau keputusan yang sekarang atau nantinya. Berdasarkan pendapat yang di kemukakan di atas dapat ditarik kesimpula bahwa informasi adalah data yang sudah diolah, dibentuk atau dimanipulasi sesuai dengan keperluan tertentu.

\subsection{Definisi Data}

Menurut Agus Mulyanto (2009:15), Data adalah kenyataan yang menggambarkan suatu kejadian-kejadian dan kesatuan nyata. Kejadian (event) adalah sesuatu yang terjadi pada saat tertentu. Kesatuan nyata (fact and entity) adalah berupa suatu objek nyata seperti tempat, benda, dan orang yang betul-betul ada dan terjadi. Sumber dari informasi adalah data. Data merupakan bentuk jamak dari bentuk tunggal data item. Data adalah fakta-fakta, simbol/karekter, data mentah atau observasi yang menggambarkan suatu fenomena tertentu. Misalnya temperatur sekarang, harga suatu suku cadang, dan umur anda, semua itu adalah data Suber informasi adalah data juga merupakant bentuk tunggal yang menggambarkan suatu kenyataan yang terjadi pada saat tertentu.

\subsection{Sistem Penggajian}

Sistem informasi penggajian dapat digunakan oleh manajemen perusahaan untuk merencanakan dan mengendalikan operasi perusahaan. Secara umum sistem informasi akuntansi penggajian adalah suatu sistem akuntansi yang digunakan untuk menangani pembayaran atas pengeyarah jasa yang dilakukan oleh karyawan yang mempunyai jenjang jabatan manajer. Penggajian menurut Mulyadi (2013:5) adalah pembayaran atas penyerahan jasa yang dilakukan oleh karyawan yang mempunyai jenjang jabatan manajer, umumnya di bayar tetap perbulan. Gaji adalah jumlah pembayaran jasa yang di bayarkan setiap bulan. gaji adalah balas jaasa yang dibayarkan secara periode kepada karyawan tetap serta mempunnyai jaminan yang pasti.

\subsection{Hubungan Sistem Informasi Akuntansi Dengan Penggajian}

Terdapat beberapa pengertian mengenai sistem informasi akuntansi penggajian yang dikemukakan oleh para ahli. Salah satunya adalah Mulyadi (2013:17) yang mengatakan bahwa sistem akuntansi penggajian dirancang untuk menagani transaksi perhitungan gaji karyawan dan pembayarannya, perancangan sistem akuntansi penggajian dan pengupahan ini harus dapat menjamin validitas, otorisasi kelengkapan, klasifikasi penelitian, ketepatan, waktu dan posting serta ikhtisaran dari setiap transaksi penggajian dan pengupahan. Sistem akuntansi gaji untuk kebanyakan perusahaan adalah suatu sistem dari prosedur dan catatancatatan yang memberikan kemungkinan untuk menentukan dengan cepat dan tepat berapa jumlah pendapatan kotor setiap pegawai, berapa jumlah yang harus dikurangi dan pendapatan untuk berbagai pajak dan potongan lainnya dan berapa saldo yang harus diberikan kepada karyawan.

\subsection{Pengendalian Intern}

(Diana dan Setiawati, 2012:82) Pengendalian internal adalah semua rencana organisasional, metode dan pengukuran yang dipilih oleh suatu kegiatan usaha untuk mengamankan harta kekayaanya, mengecek keakuratan dan keandalan data akuntansi usaha tersebut, meningkatkan efisiensi operasional, dan mendukung dipatuhinya kebijakan manajerial yang telah ditetapkan. (tuanakotta, 2013) Pengendalian internal dirancang, di implementasikan, dan dipelihara oleh pemilik perusahaan, manajemen, dan karyawan untuk menangani resiko bisnis dan resiko kecurangan yang diketahui mengancam pencapaian tujuan entitas, seperti pelaporan keuangan yang andal.

\subsection{Penelitian Terdahulu}

1. Penelitian yang dilakukan Faizal (2013) hasil penelitiannya menunjukkan sistem manual yang digunakan oleh PT. Campaka Pribumi Mandiri kurang efektif, efisien dan akurat dalam hal perhitungan gaji dan penyajian laporan gaji. 
2. Penelitian yang dilakukan Iradatul (2015) hasil penelitiannya sistem akuntansi penggajian dan pengupahan sudah cukup baik diterapkan tetapi masih terdapat beberapa kekurangan sehingga belum dapat tercipta pengendalian intern yang baik bagi perusahaan.

\section{METODE PENELITIAN}

\subsection{Jenis dan Sumber Data}

Penelitian ini adalah penelitian kualitatif yaitu penelitian deskripti yang mencari jawaban secara dasar sebab akibat, dengan menganalisis faktor-faktor penyebab terjadinya atau munculnya suatu fenomena tertentu. Penelitian ini bertujuan untuk mengetahui bagaimana sistem informasi akuntansi penggajian pada RSUP.Prof.Dr.R.D.Kandou Manado. Data dari penelitian ini berasal dari dua sumber, Yaitu :

1. Data primer, data yang diambil secara langsung dari pihak perusahaan melalui wawancara untuk memperoleh data atau survei lapangan dengan metode pengumpulan data yang diperoleh dan dikumpul langsung dari RSUP.Prof.Dr.R.D.Kandou Manado. Data Primer yang digunakan Adalah : 1) Perekrutan karyawan 2) Penetapan Gaji 3) Dokumen-Dokumen Penggajian 4) Pencatatan Akuntansi 5) Fungsi-Fungsi yang terkait dalam Penggajian 6) Prosedur-Prosedur dalam sistem penggajian.

2. Data sekunder, yaitu data yang biasanya diperoleh dari luar perusahaan, selain itu juga data sekunder dalam penelitian ini diperoleh dari berbagai macam buku, dan sumber lain yang berhubungan dengan penelitian ini.

\subsection{Metode Analisis Data}

Adapun metode analisis data yang digunakan dalam penelitian ini adalah analisis kualitatif atau deskriptif yaitu suatu bentuk penelitian yang bertujuan untuk mendeskripsikan fenomena-fenomena yang ada, baik fenomena alamiah maupun fenomena buatan manusia. Fenomena ini biasanya berupa bentuk, aktivitas, karakteristik, perubahan, hubungan, kesamaan, dan perbedaan antara fenomena yang satu dengan fenomena lainnya.

\section{HASIL ANALISIS DAN PEMBAHASAN}

\subsection{Hasil Analisis}

1) Perekrutan Karyawan

Penerimaan pegawai dilakukan fengan pemberitaan di media Masa, kemudian diseleksi dan ditranig untuk menentukan apakah calon karyawan mempunyai kompetensi sesuai bidangnya. Syarat-syarat yang harus dipenuhi oleh setiap pelamar adalah kewarganegaraan Indonesia, berusia 18 Tahun sampai dengan 30 Tahun, mempunyai pendidikan, kecakapan atau keahlian yang diperlukan, berkelakuan baik, berbadan sehat dan lulus ujian sekolah menengah ke atas atau perguruan tinggi. Setiap pelamar harus menunjukan surat lamaran yang ditulis dengan tulisan tangan sendiri dengan disertai daftar riwayat hidup, Salinan ijazah atau surat tanda tamat belajar yang diperlukan, surat keterangan berkelakuan baik dari kepolisian,, surat keterangan kesehatan dari dokter, pas foto menurut ukuran dan jumlah yang ditetapkan, Salinan sah suratt keputusan untuk keterangan tentang pengalaman kerja bagi pelamar yang telah mempunyai pengalaman kerja , surat keterangn lainya yang diperlukan ketika pegawai mulai dipekerjakan, pegawai melengkapi formulir pegawai baru.

2) Penetapan Gaji

Perusahaan memberikan imbalan kepada karyawan berupa gaji yang dilakukanya, gaji yang diberikan terdiri dari Gaji pokok, Tunjangan Jabatan, Tunjangan Uang makan, Tunjangan Transportasi, Tunjangan uang lembur dan Bonus. Perhitungan gaji pokok didasarkan pada 
peraturan pemerintah tentang upah minimum Provinsi (UMP), Perhitungan uang Tunjangan, Uang lembur dan insentif atau bonus didasarkan pada surat keputusan pimpinan perusahaan. Dalam memberikan Gaji, perusahaan juga memberikan potongan. Potongan-Potongan gaji terdiri dari potongan pajak penghasilan (PPH21), iuran Jaminan hari Tua (JHT), Iuran Kesehatan (BPJS) atau asuransi swadana lainnya dan potongan-potongan lainnya yang diatur oleh perusahaan berupa potongan gaji karena keterlambatan masuk kerja atau tidak masuk kerja tanpa izin. Sistem penggajian karyawan Yaitu Perbulan, Tidak menggunakan sistem upah Harian.

3) Dokumen yang diperlukan

Dokumen yang digunakan dalam sistem penggajian pada RSUP.Prof.Dr.R.D.Kandou Manado adalah :

a. Data Pegawai

Dokumen ini berisi tentang data pegawai/ karyawan yang diterima bekerja di perusahaan. Dokumen ini dibuat berdasarkan pegawai baru yang diisi pada saat pegawai mulai dipekerjakan.

b. Dokumen pendukung perubahan gaji

Dokumen ini dikeluarkan oleh bagian personalia berupa surat keputusan yang berhubungan dengan perubahan gaji yang meliputi pengangkatan karyawan baru dan perubahan dan kenaikan jabatan karyawan.

c. Daftar Hadir

Dokumen ini berisi nama karyawan, bagian, jabatan dan waktu kehadirannya.

d. Daftar Gaji

Dokumen ini berisi nama karyawan, bagian, jabatan dan waktu kehadirannya.

e. Rekap daftar gaji

Dokumen ini merupakan rekapitulasi dari daftar gaji karyawan.

f. Surat Tugas

Dokumen ini berisi tentang pemberian tugas kepada karyawan yang bersangkutan,nama, jabatan, bagian, tempat tujuan, jenis tugasnya, tanggal berangkat dan kembali serta kendaraan yang dipakai.

g. Bukti kas Keluar

Dokumen ini berisi uraian pengeluaran kas untuk pembayaran gaji, jumlah dan akan diperiksa terlebih dulu sebelum kas dikeluarkan. RSUP.Prof.Dr.R. D.Kandou Mando tidak berdasarkan jumlah jam hadir karyawan dan tidak menggunakan kartu jam hadir untuk mencatat kehadiran karyawan. Untuk memcatat kehadiran karyawan, perusahaan menggunkan dokumen berupa daftar hadir. Hal ini dilakukan untuk menentukan besarnya gaji karyawan. Untuk mencatat pengeluaran kas, bukti yang digunakan adalah bukti kas keluar.

RSUP.Prof.Dr.R.D.Kandou Manado tidak menggunakan amplob gaji karena pembayaran gaji dilakukan dengan cara mentransfer melalui rekenig masing-masing karyawan. Rincian mengenai gaji pokok, tunjangan dan potongan gaji dicantumkan dalam kartu gaji/slip gaji.

4) Catatan akuntansi yang digunakan

Catatansi akuntansi yang digunakan dalam sistem penggajian pada RSUP.Prof.Dr.R.D.Kandou Manado adalah :

\section{a. Laporan Harian Kas}

Digunakan untuk mencatat uang kas yang dikeluarkan untuk pembayaran gaji karyawan, pencatatan ini dilakukan oleh fungsi keuangan.

b. Jurnal umum

Digunakan untuk mencatat pengeluaran biaya gaji karyawan. Pencatatan ini dilakukan oleh fungsi akuntansi. 
c. Buku besar

Buku besar ini merupakan kumpulan dari akun yang telah dicatat dalam jurnal umum untuk biaya gaji.

d. Kartu gaji/Slip gaji

Merupakan catatan mengenai penghasilan karyawan dan berbagai potongan yang diterima oleh karyawan. Kartu ini dipakai sebagai dasar perhitungan PPH 21 dan juga sebagai tanda terima Gaji.

5) Fungsi Yang Terkait

Fungsi yang terkait dalam sistem penggajian pada RSUP.Prof.Dr.R.D.Kandou Manado adalah sebagai berikut :

a. Fungsi Personallia

Fungsi ini pada dasarnya bertujuan untuk mengatur seluruh pegawai yang ada diperusahaan, tetapi fungsi ini juga bertugas untuk mengontrol kehadiran karyawan, mencatat waktu hadir dan membuat daftar hadir. Pencatatan waktu hadir akan menentukan gaji yang akan diterima karyawan, apakah gaji yang akan diterima utuh atau ada potongan yang disebabkan oleh keterlambatan atau ketidak hadiran karyawan.

b. Fungsi pembuat daftar gaji

Fungsi ini bertujuan untuk membuat daftar gaji karyawan yang berisi gaji pokok, tunjangan dan potongan gaji yang terjadi selama periode pemberian gaji. Dalam menentukan gaji karyawan menggunakan surat keputusan tentang perubahan gaji karyawan.

c. Fungsi keuangan

Fungsi ini bertugas mengatur pengeluaran atau pembayaran gaji karyawan dan seluruh pengeluaran yang ada diperusahaan.

d. Fungsi akuntansi

Fungsi ini bertugas untuk mencatat transaksi pembayaran gaji karyawan dan hal-hal yang berhubungan dengan pembayaran gaji.

6) Prosedur Dalam Sistem Penggajian

Prosedur dalam sistem penggajian pada RSUP.Prof.Dr.R.D.Kandou Manado adalah sebagai berikut :

A. Prosedur administrasi Personalia

Aktivitasnya adalah sebagai berikut :

a. Perekrutan karyawan yaitu melalui rekrutmen media masa, kemudian diseleksi untuk menentukan apakah calon karyawan berkopenten di bidangnya.

b. Ketika karyawan mulai dipekerjakan, mereka melengkapi formulir pegawai baru. Salinan dari formulir-formulir ini digunakan untuk membuat atau memperbaharui catatan dalam file pegawai baru atau penggajian dan kemudian disimpan dalam file tersebut.

c. Ketika terjadi perubahan status gaji seperti kenaikan gaji karena kenaikan jabatan, bagian personalia akan mengisi formulir perubahan pegawai berdasarkan surat keputusan perubahan gaji dari perus perusahaan.

B. Prosedur Pencatatan Waktu Hadir

Fungsi yang terkait dalam prosedur ini adalah fungsi personalia dengan aktivitas sebagai berikut :

a. Pencatatan waktu hadir karyawan dilakukan dipagi hari jam 08.15 WITA. Pencatatan waktu hadir menggunakan Aplication software Fingerprint.

b. Membuat daftar hadir sesuai dengan bagian karyawan yang bersangkutan.daftar hadir ini dibuat dua rangkap, yang pertama untuk bagian personalia, dan kedua diberikan kebagian pembuat daftarr gaji.

c. Menyerahkan daftar hadir ke bagian keuangan

C. Prosedur Pembuatan Daftar Gaji 
Fungsi yang terkait dalam prosedur ini adalah fungsi pembuat daftar gaji dengan aktivitas sebagai berikut :

a. Bagian pembuat daftar gaji akan menerima daftar hadir dari bagian pencatat waktu hadir.

b. Membuat daftar gaji berdasarkan surat keputusan tentang perubahan gaji yang kemudia akan dikurangi potongan PPH 21, Iuran JHT, Iuran Kesehatan dan potongan-potongan lainnya.

c. Membuat rekap daftar gaji

d. Menyerahkan rekap daftar gaji kebagian personalia untuk diperiksa dan diotorisasi.

D. Prosedur Pembayaran Gaji

Prosedur ini melibatkan fungsi personalia, Keuangan dan fungsi akuntansi dengan aktivitas sebagai berikut :

a. Fungsi personalia

1. Personalia akan menerima rakap daftar gaji dari bagian pembuat daftar gaji.

2. Memferifikasi kebenaran dan perhitungan rekap daftar gaji dengan daftar hadir.

3. Mengotorisasi rekap dan gaji. Rekap daftar gaji diserahkan kebagian keuangan dan akuntansi

b. Fungsi keuangan

1. Menerima rekap daftar gaji yang telah diotorisasi dari bagian personalia

2. Membuat kartu gaji atau slib gaji yang berisi gaji pokok, tunjangan serta potongan-potongan berdasarkan rekap daftar gaji, kartu ini dibuat tiga rangkap, rangkap pertama akan disimpan sebagai arsip, rangkap kedua akan dikirim kebagian akuntansi dan rangkap ketiga akan diberikan kepada karyawan setelah karyawan menerima gaji.

3. Dari bagian keuangan menginput rekap daftar gaji ke sistem aplikasi gaji satker (Prosedur Kementrian Keuangan)

4. Bagian keuangan akan mengeluarkan daftar gaji karyawan.

5. Setelah mengeluarkan daftar gaji karyawan bagian keuangan akan mengantar seluruh daftar gaji karyawan ke KPPN (Kantor Pelayanan Negara)

6. Selanjutnya dari KKPN akan langsung mentransfer ke rekenig masingmasing karyawan.

7. Meyerahkan bukti kas keluar ke akuntansi

8. Mencatat pengeluaran uang kas untuk pembayaran gaji karyawan pada laporan harian kas.

c. Fungsi Akuntansi

1. Menerima rekap daftar gaji dari bagian personalia dan bukti kas keluar yang telah diotorisasi dan bagian keuangan.

2. Memferivikasi bukti kas keluar dengan rekap daftar gaji.

3. Mencatat biaya gaji kedalam jurnal umum dan buku besar karyawan akan menerima perincian gaji dalam kartu gaji atau slip gaji sebagai bukti gaji

\subsection{Pembahasan} sudah diTransfer dan menandatangani kartu gaji atau slip gaji.

Penelitian terhadap fungsi-fungsi yang terkait dalam sistem penggajian karyawan pada RSUP Prof.Dr.r.d.Kandou Manado adalah :

a. Fungsi pencatatan apsensi 
Pencatatan atas kehadiran semua karyawan di RSUP Prof.Dr.R.D.Kandou Manado dilakukan dilakukan dengan menggunakan sistem software. Pencatatan ini meliputi hari, tanggal dan waktu dating, waktu kepulangan, menit kerja. Fungsi pencatatan absensi ini terpisah dari fungsi pembuat daftar gaji.

b. Fungsi administrasi personalia

Fungsi administrasi personalia di RSUP Prof.Dr.R.D.Kandou Manado ditangani langsung oleh Kabag SDM. Setelah absensi karyawan yang tercatat dalam sistem software diketahui. Tugas fungsi administrasi personalia adalah membuat rekap daftar apsensi seluruh karyawan.

c. Fungsi penggajian

Daftar gaji dibuat oleh bagian penggajian yang ditangani langsung oleh kasubag bagian perbendaharaan dan pelaksanaan penggajian atas dasar surat keputusan pengangkatan karyawan, maupun peraturan-peraturan penggajian, catatan masa kerja karyawan, jabatan dan level karyawan.

d. Fungsi divisi operasional

Berdasarkan rekap struktur gaji karyawan dari bagian sumber daya manusia (SDM). Bagian keuangan menerima berkas rekap daftar gaji karyawan untuk diinput ke sistem aplikasi gaji satker (Produk Kementrian Keuangan), dan akan mengeluarkan daftar gaji yang akan diserahkan ke KKPN untuk melakukan entry gaji ke rekenig masing-masing karyawan.

Penelitian terhadap jaringan prosedur pengendalian intern dan sistem informasi akuntansi penggajian RSUP Prof.Dr.r.d.Kandou Manado adalah :

a. Prosedur pencatatan daftar hadir

Pencatatan daftar hadir karyawan menggunakan sistem software sangat menunjang proses pencatatan waktu hadir karyawan. Bagian akuntansi tinggal mengawasi setiap karyawan yang memasukan paswordnya kedalam komputus sebagai tanda apsensi, juga adanya apsensi manual yang dapat menunjang data dari absensi sistem software.

b. Prosedur administrasi personalia

Prosedur administrasi yang langsung ditangani oleh kasubag bagian SDM ini melakukan kegiatan pencatatan dan pengarsipan daftar apsensi tugas masing-masing. Pembayaran gaji karyawan di RSUP Prof.Dr.r.d.Kandou Manado tidak dilakukan dalam bentuk uang kas yang diberikan langsung ke karyawan, melainkan gaji dibayarkan oleh kantor pelayanan perbendaharaan negara (KPPN) dengan entry gaji ke rekenig masingmasing karyawan.

c. Struktur Organisasi

Struktur organisasi RSUP.Prof.Dr.R.D.Kandou Manado sudah menunjukan adanya pemisahan tanggung jawab fungsi-fungsi yang terkait dalam sistem penggajian dengan memberikan kewenangan terhadap masing-masing baian dengan proses pelaksanaan prosedur penggajian sebagai berikut :

a. Pemisahan fungsi pembuat daftar gaji dari fungsi keuangan dan keuangan terpisah dari fungsi akuntansi.

b. Pemisahan terhadap fungsi pencatat waktu hadir dari fungsi pembuat daftar gaji.

d. Sistem Otorisasi

Sistem otorisasi yang berlaku dalam sistem penggajian dalam RSUP.Prof.Dr.R.D.Kandou Manado adalah :

a. Karyawan yang namanya tercantum dalam daftar gaji telah mengisih dan menandatangani formulir data karyawan ketika karyawan diterima bekerja diperusahaan dan ditanda tangani oleh pemimpin perusahaan. Karyawan harus memiliki SK pengangkatan sebagai keryawan yang ditanda tangani oleh pejabat yang berwenang dalam hal ini ketua pengurus 
b. Apsensi sebagai pedoman pembuat daftar gaji diotorisasi oleh fungsi pencatat waktu hadir yang dipegang oleh bagian akuntansi.

c. Setiap terjadi perubahan gaji karyawan karena perubahan jabatan didasarkan pada surat keputusan pimpinan. Perubahan gaji karyawan atau perubahan unsur yang dipakai sebagai dasar untuk menghitung penghasilan karyawan diotorisasi oleh yang berwenang dalam hal ini Kasubag SDM.

d. Setiap potongan atas gaji karyawan selain dari pajak penghasilan karyawan dan iuran JHT didasarkan atas surat potongan gaji yang diotorisasi oleh fungsi keuangan.

e. Rekap daftar gaji diotorisasi oleh fungsi personalia.

f. Bukti kas keluar diotorisasi fungsi keuangan.

g. Perosedur pencatatan

e. Perubahan dalam pencatatan penghasilan karyawan direkonsiliasi dengan daftar gaji karyawan.

f. Pengeluaran biaya gaji dicatat dalam dua pencatatan yaiut laporan harian kas dan jurnal umum. Kedua pencatatan tersebut dicatat oleh fungsi keuangan dan jurnal umum dicatat oleh fungsi akuntansi. Kedua fungsi ini saling mengadaka rekonsiliasi apabila selisih saldo kas.

g. Praktik yang sehat

Praktik yang sehat dalam pelaksanaan tuguas dan fungsi yang diterapkan disetiap unit organisasi pada RSUP.Prof.Dr.R.D.Kandou Manado adalah :

a. Pencatatan waktu hadir menggunakan software finger print. Hal ini dapat meminimalisir terjadinya manipulasi daftar hadir oleh bagian pencatat waktu hadir. Fungsi pencatat waktu hadir dipegang oleh bagian akuntansi, mengawasi sistem softwate pencatat absensi karyawan.

b. Pembuat daftar gaji diferivikasi kebenaran dan ketelitian perhitungannnya oleh fungsi akuntansi sebelum dilakukan pembayaran.

c. Daftar gaji diferivikasi kebenaran dan ketelitian perhitungannya oleh fungsi personalia.

d. Perhitungan pajak penghasilan karyawan dan potongan-potongan lainnya direkonsiliasi dengan kartu gaji/slip gaji.

e. Pembayaran gaji karyawan akan di transfer langsung dari kantor pelayanan perbendaharaan negara (KPPN), ke rekenig masing-masing karyawan dengan cara ini pembayaran gaji sudah sangat efektif karena bias mengetahui sebab-sebab terjadinya perbedaan di antara saldi kas menurut laporan (KPPN) dan saldo menurut pembukuan rumah sakit. Dari hasil penelitian ini penulis, dapat menyimoulkan bahwa sistem penggajian pada RSUP.Prof.Dr.R.D.Kandou Manado sudah sangat Baik.

f. Daftar gaji di simpan oleh fungsi daftar gaji.

g. Catatan penghasilan karyawan disimpan oleh fungsi pembuat daftar gaji yang dipegang oleh manajer SDM. 


\subsubsection{Perbandingan Unsur-Unsur pengendalian Intern}

\begin{tabular}{|c|c|c|c|}
\hline No & $\begin{array}{l}\text { Unsur Pengendalian } \\
\text { Intern COSO }\end{array}$ & $\begin{array}{l}\text { Unsur pengendalian Intern } \\
\text { Rumah sakit }\end{array}$ & Keterangan \\
\hline 1 & $\begin{array}{l}\text { Lingkungan } \\
\text { pengendalian }\end{array}$ & $\begin{array}{l}\text {-Integritas dan nilai-nilai etika. } \\
\text { Kebersamaan,Profesionalisme, } \\
\text { Kejujuran,keterbukaan. } \\
\text {-komitmen terhadap kompetensi. } \\
\text { Menigkatkan sarana prasarana } \\
\text { rumah sakit dalam memberikan } \\
\text { pelayanan, Meningkatkan kualitas } \\
\text { pelayanan kesehatan kepada } \\
\text { masyarakat di kawasan timur } \\
\text { Indonesia. }\end{array}$ & Sudah Efektiv \\
\hline 2 & Penaksiran resiko & $\begin{array}{l}\text {-Resiko klinis yaitu semua isu yang } \\
\text { dapat berdampak terhadap } \\
\text { pencapaian pelayanan pasien yang } \\
\text { bermutu tinggi, aman dan efektif. } \\
\text {-Resiko non klinik adalah semua } \\
\text { issu yang dapat berdampak terhadap } \\
\text { pencapaian tugas pokok dan } \\
\text { kewajiban hukum dari rumah sakit } \\
\text { sebagai korporasi. }\end{array}$ & Sudah efektiv \\
\hline 3 & $\begin{array}{l}\text { Aktivitas } \\
\text { Pengendalian }\end{array}$ & $\begin{array}{l}\text {-Pemisahan fungsi pembuat daftar } \\
\text { gaji dari fungsi keuangan dan } \\
\text { keuangan terpisah dari fungsi } \\
\text { akuntansi. } \\
\text {-Pemisahan terhadap fungsi pencatat } \\
\text { waktu hadir dan fungsi pembuat } \\
\text { daftar gaji. } \\
\text {-Pemisahan fungsi pembuat daftar } \\
\text { gaji dari fungsi keuangan dan } \\
\text { keuangan terpisah dari fungsi } \\
\text { akuntansi. }\end{array}$ & Sudah Efektiv \\
\hline 4 & $\begin{array}{l}\text { Informasi dan } \\
\text { komunikasi }\end{array}$ & $\begin{array}{l}\text {-Informasi dan komunikasi yang ada } \\
\text { di rumah sakit sudah sangat } \\
\text { memadai karena sudah ada } \\
\text { pengendalian inter SIA yang } \\
\text { mengatur seluruh informasi } \\
\text { keuangan dan di sajikan dalam } \\
\text { bentuk yang lebih jelas dan akurat. }\end{array}$ & Sudah Efektiv \\
\hline 5 & Pemantauan & $\begin{array}{l}\text {-pemantauwan yang terjadi di rumah } \\
\text { sakit masih ada sedikit ke lemahan } \\
\text { yaitu dimana bagian pengawasan } \\
\text { penggajian dilakukan setiap tiga } \\
\text { bulan sekali.. tapi mulai akan di } \\
\text { terapkan sebulan sekali. }\end{array}$ & Sudah efektiv \\
\hline
\end{tabular}




\section{KESIMPULAN DAN SARAN}

\subsection{Kesimpulan}

Setelah melakukan pembahasan mengenai prosedur yang diterapkan sistem akuntansi penggajian pada RSUP.Prof.Dr.R.D.Kandou Manado, maka penulis dapat mengambil kesimpulan sebagai berikut :

Sistem informasi akuntansi penggajian yang diterapkan dalam perusahaan adalah sistem gaji tetap bervariasi. Karyawan perusahaan mendapat gaji tertentu, tetapi bila lembur atau melakukan prestasi tertentu akan mendapatkan uang tambahan, sebaliknya bila tidak masuk kerja gajinya tidak akan langsung dipotong pada gaji pokok, tetapi tunjangan yang akan dikurangi. Unit-unit yang terkait dalam sistem informasi akuntansi penggajian yaitu unit SDM dan Keuangan. Dokumen yang digunakan dalam sistem informasi akuntansi penggajian adalah daftar kehadiran, perhitungan gaji bulanan, Daftar trasfer gaji dan slip gaji.

Sistem informasi akuntansi yang diterapkan oleh RSUP.Prof.Dr.R.D.Kandou Manado telah mempunyai sistem yang baik dan efektif serta memenuhi unsur-unsur pengendalian intern sehingga menigkatkan kinerja perusahaan. Dengan adanya sistem informasi akuntansi penggajian terkomputerisasi dapat menghemat waktu yang diperlukan untuk membuat berbagai macam laporan seperti laporan pegawai, Laporan lembur, Laporan penggajian dan laporan rekapitulasi dana secara cepat dan jelas. Informasi data yang disajikan menjadi lebih akurat dan tingkat ketelitian lebih tinggi sehingga kemungkinan menbuat kesalahan sangatlah kecil dan koreksi data dapat dilakukan sewaktu-waktu dan dilaksanakan dengan cepat dan mudah. Misalnya bila terjadi suatu kesalahan akan sangat cepat ditemukan dan segera dapat dibenarkan saat itu juga. Namun masih terdapat sedikit kelemahan yaitu bagian pengawasan penggajian dilakukan setiap Tiga bulan sekali.

\subsection{Saran}

Saran yang dapat penulis berikan dalam penelitian ini adalah manajer RSUP.Prof.Dr.R.D.Kandou Mando sebaiknya melakukan pengawasan berkala setiap bulannya dalam proses pembuatan daftar gaji. Hal ini dilakukan untuk menghindari terjadinya kecurangan dalam proses penggajian.

Dalam pengelolaan data penggajian yang ada pada RSUP.Prof.Dr.R.D.Kandou Manado diperlukan juga adanya perawatan, baik hardware maupun softwarenya agar keamanan data tetap terjaga dan proses administrasi dapat berlangsung dengan lancar, cepat dan benar.

\section{DAFTAR PUSTAKA}

Anastasia Diana, Lilis Setiawati (2012). Sistem Informasi Akuntansi, Perancangan, Proses dan Penerapan. Edisi I. Yogyakarta: Andi Yogyakarta

Faizal (2013) Sistem Informasi Akutansi Penggajian Karyawan Pada Pt. Campaka Pribumi Mandiri. Jurnal Teknologi Informasi Dan Komunikasi. Stmik Subang. Vol. 2. No.1

Gaol, L, Jimmy. 2008. Sistem Informasi Manajemen Pemahaman dan Aplikasi. Jakarta : Penerbit PT Grasindo.

Gelinas, J.U., Dull, Richard B., Wheeler, Patrick R. 2012. Accounting Information Systems. South Western: Cengage Learning

Harahap, Sofyan. 2013 Analisis Kritis Atas Laporan Keuangan. Penerbit Rajawali Pers. Jakarta

Iradatul(2015) Analisis Sistem Akuntansi Penggajian Dan Pengupahan Dalam Upaya Mendukung Pengendalian Intern (Studi Pada Pt. Sun Star Motor Malang). Jurnal Administrasi Bisnis. Universitas Brawijaya. Vol.25 No 2. 
Kieso, D. E., Weygandt, J. J., \& Warfield, T. D (2011). Intermediate Accounting Volume 1 IFRS Edition. United States of America : Wiley.

Mulyadi. 2013. Sistem Akuntansi. Jakarta: Salemba Empat.

Pontoh, Winston, 2013. Akuntansi Konsep dan Aplikasi. Halaman Moeka. Jakarta

Romney, paul john steninbart. 2015. Accounting information systems, $13^{\text {th }}$ ed. England: pearson educations Limited.

Tuanakotta, Theodorus M. 2013. Audit Berbasis ISA (internasional Standart on Auditing) . Jakarta: Selemba Empat. 